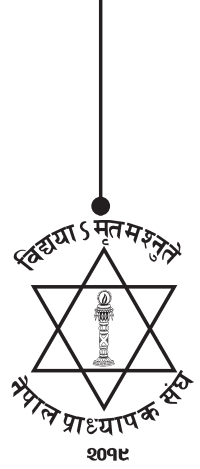

NJ: NUTA

\title{
Herbal Veterinary Practices by Tamang Community in Central Nepal
}

\author{
Ila Shrestha, PhD* and Prakash Khadgi** \\ *Reader, Patan Multiple Campus, Tribhuvan University \\ **Lecturer, Patan Multiple Campus, Tribhuvan University \\ Emails for correspondence: shrestha_ila@yahoo.com
}

\begin{abstract}
Herbal veterinary practices survey has been carried out in different areas of central Nepal among the Tamang people. Tamang people have been using the existing plant resources for different ailments to the domestic animals. This paper deals with 44 species of the herbal veterinary practices along with botanical name, Nepali name, Tamang name, family, and its uses. The knowledge of herbal practices is limited to remote areas and is descendent from generation to generation. Consequently, curing of the disease by using herbal plants is one of the most important prevailing systems in central Nepal where the veterinary hospitals are in very poor condition.
\end{abstract}

Key words: Medicinal plants, herbal veterinary practices, domestic animal and Tamang people.

\section{Introduction}

Nepal is significantly rich in terms of biodiversity (B), cultural diversity (C) and linguistic diversity (L), called three fold living environment. Every organism is a unique and dependent and there is a casual relationship among BCL while existing in the nature (Grin, 1990). Nepal holds 11th position in Asia and 25th position in the world in terms of spices richness with 2 percent world flowering plant, 3 percent herbal plant, 4 percent mammalians, 9 percent birds (Hada, 2007). Similalry, there are 125 ethnic groups and 123 lingusitc groups in Nepal (Central Bureau of Statistics [CBS], 2011). Cultural diversity can be transformed from generation to generation through Mother Tongue Language (MTL) that respect nature (Awasthi, 2004). After 1960, MTL has been considered as scientific knowledge that is practicing for natural resource management (Pardhan \& Pardhan, 2006). In this context, this paper highlighted how Tamang people are managing ethno medicine or herbal plants from generation to generation. Out of total population $26,494,504$ of the country there are $5.8 \%$ or $1,539,830$ Tamang people in Nepal (CBS, 2011).

Ethno medicine is an integral part of the socio-economic life of the people living in different ecological regions (i.e. Mountain, Hill and Terai). However, practices of ethno medicine vary from one region to another. Majorities of the rural people are dependent on agriculture and animals for livelihood. The people are conscious for the health and have been dependent on the herbal practices for their domestic animals since time memorial (Manandhar, 2002).

NUTA JOURNAL, 6 (1\&2), 2075 : ISSN: 2616 - 017x 
There is no mechanism to acquire ethno medicinal knowledge from generation to generation. Owing to that any ethnic groups are compelling to acquire such knowledge and skills partially by trial methods from their ancestors. There was/is minimal investigation efforts done on ethno medicine, although some attempts have been made recently by Chaudhary (1994), Joshi (1979), Shrestha (1998) in Nepal and Pal (1981), Pandey et al., (2000), Reddy and Raju (2000) in India. Therefore, the study was undertaken with a view to explore ethno medicinal practices of Tamang people and suggest preserving their traditional knowledge and skills related to herbal plants.

\section{Material and Methods}

The field study was carried out in Makawanpur, Kathmandu, Lalitpur, Bhaktapur, Sindhupalchowk, Kabhrepalanchowk, Rasuwa, Nuwakot, Dhading, Kaski and Lamjung districts of Central Nepal during the period 1986 to 2013. In the course of field survey, the data was obtained through interviewing with local Tamang communities by visiting house to house. Information on herbal veterinary plants practices for domestic animals were also achieved from traditional healers and other experienced informants. Information of the herbal veterinary plants was recorded in their own Tamang language, includes common vernacular names of the plants; part used, preparation of medicine, mode of application, dosage and duration of treatment and precautions. All the plants were collected in the field and identified in the field and National Herbarium and Plant Laboratories (KATH).

\section{Results}

Explored species are arranged alphabetically according to their botanical names, family, Nepali name, Tamang names and forms and uses of those plants in the table number 1 and 2 as well.

Table 1. Descriptions of Herbal Plants

\begin{tabular}{|c|c|c|c|c|c|}
\hline $\mathrm{SN}$ & Botanical Name & Family & Nepali Name & Tamang Name & Forms and Uses \\
\hline 1 & $\begin{array}{l}\text { Adiantum } \\
\text { venustum D.Don }\end{array}$ & Pteridaceae & Sinke & Bhasipsip & $\begin{array}{l}\text { Leaves and rhizome juice are } \\
\text { poured externally in the cuts and } \\
\text { septic wounds particularly yak and } \\
\text { nak. }\end{array}$ \\
\hline 2 & $\begin{array}{l}\text { Atylosia } \\
\text { scarabaeoides (L.) } \\
\text { Benth. }\end{array}$ & Leguminosae & $\begin{array}{l}\text { Bhatmase } \\
\text { ghans }\end{array}$ & Sakino & $\begin{array}{l}\text { Fresh plant is given to the cattlle } \\
\text { in diarrhoea. }\end{array}$ \\
\hline 3 & $\begin{array}{l}\text { Bistorta milletii } \\
\text { Lev. }\end{array}$ & Polygonaceae & Mhykure & Rangrung & $\begin{array}{l}\text { Fresh plant is given as nutritious } \\
\text { food and to enhance the secretion } \\
\text { of milk particularly nak. }\end{array}$ \\
\hline 4 & $\begin{array}{l}\text { Bistorta } \\
\text { vaccinifolia (Wall. } \\
\text { ex Meisn.) Greene }\end{array}$ & Polygonaceae & Phulunge jhar & Tolowang & $\begin{array}{l}\text { About } 100 \mathrm{ml} \text { of extracted root } \\
\text { juice is given orally to relief the } \\
\text { fever. }\end{array}$ \\
\hline 5 & $\begin{array}{l}\text { Boenninghausenia } \\
\text { albiflora (Hook.) } \\
\text { Rehb.ex Meisn. }\end{array}$ & Rutaceae & Dampate & Urmen & $\begin{array}{l}\text { Plant powder is applied all over } \\
\text { the body externally to remove the } \\
\text { parasitic insect. }\end{array}$ \\
\hline 6 & Bombax ceiba $\mathrm{L}$. & Bombacaceae & Simal & Kakdhong & $\begin{array}{l}\text { Bark is boiled with water and } \\
\text { extract is applied for the boils. }\end{array}$ \\
\hline 7 & $\begin{array}{l}\text { Campylotropis } \\
\text { speciosa } \\
\text { (Royle ex } \\
\text { Schindl.) Schindl. }\end{array}$ & Leguminosae & Sakino & Mena & $\begin{array}{l}\text { Leaves paste is applied over the } \\
\text { dislocated bones to hasten up the } \\
\text { process of healing particularly for } \\
\text { the cows. }\end{array}$ \\
\hline
\end{tabular}

(Continued...) 
(Table 1. continued...)

8 Cannabis sativa L. Cannabaceae Bhang Sima Fresh leaves and inflorescence

9 Cassiope fastigiata Ericaceae Phursan Nyamlu (Wall.) D. Don

10 Centella asiatica Umbelliferae (L.) Urb.

11 Circium argyracanthus DC.

12 Clematis buchananiana DC. Compositae
Ranunculaceae Junge lahara
13

Colebrookia oppositifolia Sm.

14 Cuscuta reflexa Roxb.

15 Cymbopogon
flexuosus (Nees ex Steud) W. Watson.

16 Daphne bholua Buch.-Ham ex D. Don

17 Drynaria propinqua (Wall. ex Mett.) J.Sm. apud Bedd.

18 Edgaria darjeelingensis $\mathrm{C}$.

B. Clarke

19 Ephedra gerardiana Wall. Ex Stapf.

20 Equestum debile Roxb.

Labiatae

Cuscutaceae

Nurbusi

Dhusure

Gramineae

Chel

Thymelaeaceae Kagatpate

Polypodiaceae Kamari

Cucurbitaceae

Ephedraceae

Somlata
Ghodtapre

Thakal kanda

Dhursel

Akashbeli,

Yukpa

Jangali karela

Tangsarkato

Kre

Nakabhyak

Syukudhumbu are fed with corn flour to treat the diarrhoea.

The plant powder is applied all over the swellings of the limb which are believed to be due to ghost Plants are also given to cattles for lactation.

Fresh plants are fed to the horses in case of the urinary problems.

About $100 \mathrm{ml}$ of extracted root juice is given at one time to yaks and naks in cases of constipation and urinary problem.

Pounded leaves are applied all over the burns and fed to the yaks for the inflammation during the burn.

About $200 \mathrm{ml}$ of the leaf juice is fed mixed with cattle's food to the cows as an anthelmintic

About $200 \mathrm{ml}$ of extracted plant juice is given once a day for one week in case of stomach disorders.

Leaves are given as good fodder to naks and cows to enhance the secretion of milk.

Extracted flower juice is put into the nostrils of the Yaks to remove the leech during the rainy season.

Paste of the rhizome is applied on bone fracture.

Pounded seeds are mixed with corn flour and are fed to the cattle to relieve the fever.

The leaves crushed with the roots of the Rumex nepalensis are prepared into paste and the paste is applied over the area of dislocated bone.

A paste is made from the plant and is applied over the dislocated bones of the cattle for the favorable results.

(Field Observation, 1986 to 2013). 
Table 2. Descriptions of Herbal Plants

\begin{tabular}{|c|c|c|c|c|c|}
\hline $\mathrm{SN}$ & Botanical Name & Family & $\begin{array}{l}\text { Nepali } \\
\text { Name }\end{array}$ & Tamang Name & Forms and Uses \\
\hline 21 & $\begin{array}{l}\text { Euphorbia } \\
\text { royleana Boiss. }\end{array}$ & Euphobiaceae & Seudi & Desya & $\begin{array}{l}\text { About } 100 \mathrm{ml} \text { of the plant juice } \\
\text { is fed mixed with cattle's food to } \\
\text { get rid of intestinal worms. }\end{array}$ \\
\hline 22 & $\begin{array}{l}\text { Fraxinus } \\
\text { floribunda Wall. }\end{array}$ & Oleaceae & Lakure & Lakure & $\begin{array}{l}\text { About } 100 \mathrm{ml} \text { of the juice } \\
\text { extracted from the bark is given } \\
\text { to treat the stomachache for the } \\
\text { cattle. }\end{array}$ \\
\hline 23 & $\begin{array}{l}\text { Gaultheria } \\
\text { trichophylla } \text { Royle }\end{array}$ & Ericaceae & $\begin{array}{l}\text { Nilo } \\
\text { bhuikaphal }\end{array}$ & Dabrami & $\begin{array}{l}\text { Dried leaf powder is applied over } \\
\text { the old wounds and to remove the } \\
\text { worms from the wound. }\end{array}$ \\
\hline 24 & $\begin{array}{l}\text { Ilex dipyrena } \\
\text { Wall. }\end{array}$ & Aquifoliaceae & Seto khasru & Bomsi & $\begin{array}{l}\text { Fresh leaves are fed to the cattle } \\
\text { to enhance the secretion of milk } \\
\text { and to increase strength and } \\
\text { vigor. }\end{array}$ \\
\hline 25 & $\begin{array}{l}\text { Lecanthus } \\
\text { peduncularis } \\
\text { (Royle) Wedd. }\end{array}$ & Urticaceae & Gakaleti & Tilo & $\begin{array}{l}\text { Fresh plant is fed to cattle to } \\
\text { stimulate the secretion of milk. }\end{array}$ \\
\hline 26 & $\begin{array}{l}\text { Luculia gratissima } \\
\text { (Wall.) Sweet. }\end{array}$ & Rubiaceae & $\begin{array}{l}\text { Ban } \\
\text { Kangiyo }\end{array}$ & Somrati & $\begin{array}{l}\text { About } 100 \mathrm{ml} \text {. of the bark juice is } \\
\text { given once as an anthelmintic. }\end{array}$ \\
\hline 27 & $\begin{array}{l}\text { Lindera neesiana } \\
\text { (Wall. ex Nees) } \\
\text { Kurz. }\end{array}$ & Lauraceae & Siltimur & About & $\begin{array}{l}\text { About } 100 \text { gm of powdered seeds } \\
\text { are given with liquid cattle's food } \\
\text { once a day for three days to check } \\
\text { diarrhoea and dysentery. }\end{array}$ \\
\hline 28 & $\begin{array}{l}\text { Osbeckia stellata } \\
\text { Buch.-Ham. Ex } \\
\text { D. Don }\end{array}$ & Melastomataceae & Seto chulesi & Mendorumrum & $\begin{array}{l}\text { The paste is prepared from } \\
\text { the roots and flowers and is } \\
\text { applied over the swellings of the } \\
\text { dislocated bone. }\end{array}$ \\
\hline 29 & $\begin{array}{l}\text { Oxalis corniculata } \\
\mathrm{L}\end{array}$ & Oxalidaceae & Chariamilo & Nakhrupang & $\begin{array}{l}\text { Extract of the fresh leaves is } \\
\text { applied over the boils of the } \\
\text { domestic cattle. }\end{array}$ \\
\hline 30 & $\begin{array}{l}\text { Paris polyphylla } \\
\text { Sm. }\end{array}$ & Liliaceae & Satuwa & & $\begin{array}{l}\text { About } 100 \mathrm{ml} \text { of root juice is } \\
\text { given as an anthelmintic. }\end{array}$ \\
\hline 31 & $\begin{array}{l}\text { Persicaria } \\
\text { polystachya } \\
\text { (Wall. Ex Meisn.) } \\
\text { H.Gross }\end{array}$ & Polygoniaceae & Ratnaule & Yapenguin. & $\begin{array}{l}\text { Fresh tender parts are given to } \\
\text { cattle to enhance the secretion of } \\
\text { milk. }\end{array}$ \\
\hline 32 & $\begin{array}{l}\text { Plantago erosa } \\
\text { Wall. }\end{array}$ & Plantaginaceae & Isabgol & Aitanjhar & $\begin{array}{l}\text { The extract of whole plant is used } \\
\text { for antiseptic dressings. }\end{array}$ \\
\hline 33 & $\begin{array}{l}\text { Ricinus communis } \\
\text { L. }\end{array}$ & Euphorbiaceae & Adher & Dandarobi & $\begin{array}{l}\text { Paste is made from the seeds and } \\
\text { is applied over the swollen parts } \\
\text { due to cold. }\end{array}$ \\
\hline 34 & $\begin{array}{l}\text { Rumex nepalensis } \\
\text { Sprenge. }\end{array}$ & Polygonaceae & Halhale & Alpipi & $\begin{array}{l}\text { Paste of the root is applied over } \\
\text { the dislocated bone and is also } \\
\text { applied with frame of bamboo } \\
\text { stick at the bone fracture segment } \\
\text { until relief. }\end{array}$ \\
\hline
\end{tabular}

(Continued...) 
(Table 2. continued...)

\begin{tabular}{|c|c|c|c|c|}
\hline $\begin{array}{l}\text { Sarcococca } \\
\text { coriacea (Hook.) } \\
\text { Sweet }\end{array}$ & Buxaceae & Phitphiya, & Gherpati & $\begin{array}{l}\text { About } 100 \text { gms of powdered seeds } \\
\text { are mixed with corn flour to feed } \\
\text { orally to treat the stomachache. }\end{array}$ \\
\hline $\begin{array}{l}\text { Saussurea } \\
\text { fastuosa (Decne.) } \\
\text { Sch. Bip. }\end{array}$ & Compositae & Bhukur & Jhya & $\begin{array}{l}\text { About } 100 \mathrm{ml} \text { leaf extract is given } \\
\text { to control the fever; the plant is } \\
\text { tied around the tail to stimulate } \\
\text { the milk secretion and is practiced } \\
\text { to Naks in high altitude. }\end{array}$ \\
\hline $\begin{array}{l}\text { Schima wallichii } \\
\text { (DC.) Korth. }\end{array}$ & Theaceae & Chilauni & Kyasing & $\begin{array}{l}\text { About } 200 \mathrm{ml} \text { of bark juice is } \\
\text { given once as an anthelmintic. }\end{array}$ \\
\hline $\begin{array}{l}\text { Swertia ciliata (D. } \\
\text { Don ex G.Don) } \\
\text { B.L. Burtt. }\end{array}$ & Gentianaceae & Chiraito & Hoba. & $\begin{array}{l}\text { Whole plant is cut into pieces and } \\
\text { mixed with water and about } 200 \\
\text { ml of the solution is given once a } \\
\text { day to yaks and sheep to relieve } \\
\text { the fever. }\end{array}$ \\
\hline $\begin{array}{l}\text { Symplocos } \\
\text { paniculata } \\
\text { (Thunb.) Miq. }\end{array}$ & Symplocaceae & Lodh & Syungen & $\begin{array}{l}\text { Fresh leaves are given to cattle to } \\
\text { enhance the secretion of milk. }\end{array}$ \\
\hline $\begin{array}{l}\text { Taraxacum } \\
\text { officinale Wigg. }\end{array}$ & Compositae & Tukiphool & Bhutil mendo & $\begin{array}{l}\text { Paste of the plant is applied over } \\
\text { the dislocated bones and also } \\
\text { bound in fractured bones and } \\
\text { fixed with bamboo sticks instead } \\
\text { of plaster until relief. Root and } \\
\text { leaf used for the cough. }\end{array}$ \\
\hline $\begin{array}{l}\text { Thalictrum } \\
\text { chelidonii DC. }\end{array}$ & Ranunculaceae & Dampate & Urmen & $\begin{array}{l}\text { About } 100 \mathrm{ml} \text {. of root juice is } \\
\text { given to cows to control the } \\
\text { fever. }\end{array}$ \\
\hline $\begin{array}{l}\text { Uraria lagopus } \\
\text { DC. }\end{array}$ & Leguminosae & Sano bhatte & Tewalapte & $\begin{array}{l}\text { Root crushed with turmeric is } \\
\text { applied over dislocated bones } \\
\text { and bound in fractured bone, } \\
\text { bandaged and wrapped with } \\
\text { bamboo sticks for one month; it } \\
\text { is usually practiced to the cows. }\end{array}$ \\
\hline Urtica dioca L. & Urticaceae & Sisnu, & Polo & $\begin{array}{l}\text { Fresh tender parts are given to the } \\
\text { cows to increase the secretion of } \\
\text { milk. }\end{array}$ \\
\hline $\begin{array}{l}\text { Verbascum } \\
\text { thapsus L. }\end{array}$ & Scrophulariaceae & $\begin{array}{l}\text { Bandar } \\
\text { puchhre }\end{array}$ & Pangjalu & $\begin{array}{l}\text { Roots of the plant are mixed with } \\
\text { the roots of Urtica dioca and are } \\
\text { prepared in the form of paste and } \\
\text { applied over dislocated bones. } \\
\text { Paste of the root is also applied } \\
\text { on the muscular swelling in cases } \\
\text { of phantom effect. }\end{array}$ \\
\hline
\end{tabular}

(Field Observation, 1986 to 2013).

\section{Discussions and Conclusion}

The indigenous knowledge of Tamang people on herbal plants ultimately helped to document 44 species as outcomes of three fold living environment. Those species are belonging to 33 families of veterinary medicinal plants which have been used to cure different diseases prevailing in livestock of 
central Nepal. No doubt, cultural and linguistc status of Tamang people became resources for documenting varies species. Hence, government must realize provision of UNESCO 2005 that committed to ensure promotion of diversity in cultural expression, and must establish ethnic, linguistic and geographical identity of the indigenous people based determinants of new federal democratic state mechanism (Constitution, 2015). At the same time, government must develop certain mechanism to preserve and diffuse traditional knowledge related to ethno medicine of Tamng people. All in all, nineteen types of diseases occurred and cured by these wild plants especially in cows, buffaloes, yaks, naks, sheep, goats and dogs. The maximum number of plants including Bistorta milletii, Cassiope fastigiata, Cymbopogon flexuosus, Ilex dipyrena, Lecanthus peduncularis, Persicaria polystachya, Symplocos paniculata and Urtica dioca are used to stimulate the secretion of milk. Clematis buchananiana, Ricinus communis and Centella asiatica are reported to treat burn, gout and urinary problem respectively. In this paper, among the 44 plants, were identified for lactation and fever. Bone fracture includes 8 plants each, whereas 6 plants for anthelemintic, 3 plants for cuts and wounds, stomach disorder, diarrhoea and dysentery, boils and as an insecticide embraces 2 plants each and burn, gout, and urinary problem contains 1 plant each. Plants such as Adiantum venustum, Bistorta milletii, Bistorta vaccinifolia, Campylotropis speciosa, Cassiope fastigiata, Circium argyracanthu, Clematis buchananiana, Cymbopogon flexuosus, Daphne bholua, Edgaria darjeelingensis, Ephedra gerardiana, Equestum debile, Euphorbia royleana, Gaultheria trichophylla, Ilex dipyrena, Lecanthus peduncularis, Luculia gratissima, Paris polyphylla, Persicaria polystachya, Plantago erosa, Ricinus communis, Sarcococca coriacea, Saussurea fastuosa, Swertia ciliata, Symplocos paniculata, Taraxacum officinale, Thalictrum chelidonii, Uraria lagopus, Urtica dioca and Verbascum thapsus are used in veterinary medicine. The ethno botanical information for veterinary medicine of these species are not mentioned in Manandhar, (1989, 2001), Chaudhary (1994) and other published literatures in Nepal. Therefore, detailed phytochemical and pharmacological studies are required for positive exploitation and wider application.

\section{References}

Awasthi, L. D. (2004). Exploring monolingual practices in multilingual Nepal [Unpublished Doctoral Dissertation]. Submitted to Danish University of Education Copenhagen.

Bhattarai, N. K. (1992). Folk Use of Plants in Veterinary Medicine in Central Nepal. Fitoterapia, 63 (6), 497-506.

Central Bureau of Statistics (CBS). (2011). National Population and Housing Census 2011. Author.

Chaudhary, R. P. (1994). Plants Used in the Treatment of Domestic Cattle in Narayani Zone (Central Nepal). In Proceeding of II National conference on Science and Technology, RONAST. Kathmandu, 835-847.

Constitution of Nepal (2015). Constitution of Nepal 2072 BS. Kathmandu: Lumbini Pustak Pasal.

Grin, F. (1990). The Economic Approach to Minority Language. Journal of Multilingual and Multicultural Development, 11 (1\&2), 153-175.

Hada, G. B. (2007). Sustainable Rural Development. Kathmandu: Dikshant Pustak Bhandar.

Joshi, D. D. (1979). Role of Indigenous Drugs in Veterinary Medicines. Journal of Nepal Pharm. Association, 8, 37-39.

Manandhar, N. P. (1989). Ethno veterinary Medicinal Drugs of Central Development of Nepal. Bull. Med. Ethno. Bot. Res, 10 (3-4), 93-99. 
Manandhar, N. P. (2001). Herbal Veterinary Practices in Nepal. Nepal Journal of Science and Technology, 3, 65-68

Manandhar, N. P. (2002). Plants and people of Nepal. USA: Timber Press

Pal, D. C. (1981). Plants Used in Treatment of Cattle and Birds Among Tribals of Eastern India.

Pandey, H.,Verma, P \& Narain, S. (2000). Ethnoveterinary Plants in Gonda Region of Utter Pradesh India. In J.K Maheswari (Ed.), Ethnobotany and Medicinal Plants of Indian sub continent Scientific Publisher (pp. 199-203).

Pardhan, P. K. \& Pradhan, B. (2006). Environment and natural resources: Concept, method and planning. Kathmandu: Quest Publication.

Reddy, K. N. \& Raju, R. R (2000). District, Andhra Pradesh. In J. K. Maheswari (Ed.), Plants in Ethnoveterinary Practices in Anatapur Ethnobotany and Medicinal Plants of Indian Sub Contient (pp. 347-357). Scientific Publisher.

Shrestha, K. (1998). Dictionary of Nepalese Plant Names. Kathmandu: Mandala Book Point. 